\title{
Genetic variance in Nitric Oxide Synthase and Endothelin Genes among children with and without Endothelial Dysfunction
}

Siriporn Chatsuriyawong ${ }^{1,2}$, David Gozal', Leila Kheirandish-Gozal', Rakesh Bhattacharjee ${ }^{1}$, Ahamed A Khalyfa', Yang Wang ${ }^{1}$, Hakon Hakonarson ${ }^{3}$, Brendan Keating ${ }^{3}$, Wasana Sukhumsirichart ${ }^{2}$ and Abdelnaby Khalyfa ${ }^{1 *}$

\begin{abstract}
Background: The presence of endothelial dysfunction (ED) constitutes an early risk factor for cardiovascular disease (CVD) in children. Nitric oxide (NO) and endothelin (EDN) are generated in endothelial cells and are critical regulators of vascular function, with ED resulting from an imbalance between these two molecules. We hypothesized that genetic variants in NO synthase and EDN isoforms and its receptors (EDNRA and EDNRB) may account for a proportion of the risk for ED in developing children.

Methods: Consecutive children (ages 5-10 years) were prospectively recruited from the community. Time to peak postocclusive reperfusion (Tmax) was considered as the indicator of either normal endothelial function (NEF; Tmax $<45 \mathrm{sec}$ ) or ED (Tmax $\geq 45 \mathrm{sec}$ ). Lipid profiles, high sensitivity C-reactive protein (hsCRP), fasting glucose and insulin were assayed using ELISA. Genomic DNA from peripheral blood was extracted and genotyped for NOS1 (209 SNPs), NOS2 (122 SNPs), NOS3 (50 SNPs), EDN1 (43 SNPs), EDN2 (48 SNPs), EDN3 (14 SNPs), EDNRA (27 SNPs), and EDNRB (23 SNPs) using a custom SNPs array. Linkage disequilibrium was analyzed using Haploview version 4.2 software.

Results: The relative frequencies of SNPs were evaluated in 122 children, 84 with NEF and 38 with ED. The frequencies of NOS1 (11 SNPs), and EDN1 (2 SNPs) were differentially distributed between NEF vs. ED, and no significant differences emerged for all other genes. Significant SNPs for NOS1 and EDN1 SNPs were further validated with RT-PCR.

Conclusions: Genetic variants in the NOS1 and EDN1 genes appear to account for important components of the variance in endothelial function, particularly when concurrent risk factors such as obesity exist. Thus, analysis of genotype-phenotype interactions in children at risk for ED will be critical for more accurate formulation of categorical CVD risk estimates.
\end{abstract}

Keywords: NOS, EDN, Endothelial, Endothelial dysfunction, SNP, Children

\section{Background}

Obesity is one of the world's greatest public health challenges affecting not only developed, but also developing countries. The presence of obesity has now been conclusively linked to heightened morbidity and mortality through increased risk for many chronic diseases, including type-2 diabetes, hypertension, dyslipidemia, and coronary artery disease [1-4]. The pathogenesis of obesity is

\footnotetext{
* Correspondence: akhalyfa@uchicago.edu

'Department of Pediatrics, Comer Children's Hospital, Pritzker School of Medicine, Biological Sciences Division, The University of Chicago, 900 E, 57th Street, KCBD, 4112, Chicago 60637, IL, USA

Full list of author information is available at the end of the article
}

multifactorial incorporating both genetics and lifestyle. In children, obesity is associated with increased risk for multifaceted derangements in metabolic and cardiovascular function, including endothelial dysfunction (ED) [5-8]. In general terms, overweight children are more likely to prematurely develop ED, hypertension and type 2 diabetes, an array of conditions that would normally be only found in older obese adults [4]. Recently, we have shown that obesity in children is associated with an increased risk for the development of ED prior to the onset of hypertension [7]. However, not every obese child will develop ED, suggesting that both genetic and environmental factors may play a role. Conversely, a small subset of otherwise

\section{() Biomed Central}


healthy children who are not obese may manifest abnormal endothelial function, and such functional phenotype may be determined by genetic variance in endothelial function-related genes.

$\mathrm{ED}$, an early risk marker of cardiovascular disease, refers to a loss of normal homeostatic function in the blood vessels and is characterized by altered vasodilatory and vasoconstrictive functions and inflammatory activity [9]. ED is involved in the development of vascular complications related to dyslipidemia, and cardiovascular disease such as hypertension, coronary artery disease and chronic heart failure [10,11]. A major contributor of ED involves reductions in the amount of bioavailable nitric oxide (NO) in the vasculature [12]. Indeed, NO is an important factor in endothelial functional homeostasis, and also inhibits platelet aggregation, leukocyte adhesion, smooth muscle cell migration and proliferation [13], as well as oxidation of atherogenic low-density lipoprotein [14]. NO is synthesized from the amino acid L-arginine in endothelial cells, as well as many other cell types by three nitric oxide synthase (NOS) isoforms; neuronal (nNOS, NOS1), inducible (iNOS, NOS2), and endothelial (eNOS, NOS3) [15-18]. NOS1 and NOS3 genes are constitutively expressed resulting in a low basal synthesis of NO $[19,20]$, whereas induction of NOS2 expression is regulated by transcription factors such as nuclear factor $\kappa B\left(\mathrm{NF}_{-\mathrm{K}} \mathrm{B}\right)$ [21]. Several studies have examined the possibility that genetic variants in the genes encoding these enzymes could influence their expression and functional activity, potentially altering the predisposition to cardiovascular disease [22,23]. Accordingly, single nucleotide polymorphisms (SNPs) have been identified in NOS genes, and their association with coronary artery disease, hypertension, and diabetes has been explored [24-26]. To the best of our knowledge, the potential associations between NOS polymorphisms and ED are currently unexplored in children.

The endothelin (EDN) system consists of three endothelin isoforms (EDN1, EDN2 and EDN3), and two receptors (endothelin type A and type B) linked to multiple signaling pathways [27]. Endothelins (EDN1, EDN2 and EDN3) are 21-amino acid peptides that exert their effects through their cognate receptors EDNRA and EDNRB with different degrees of binding affinity. Various SNPs have been identified on EDN genes and EDNRA and EDNRB receptors genes, and have been associated with susceptibility and prognosis of diseases such as heart failure, dilated cardiomyopathy, diabetic retinopathy, and atherosclerosis [28-32]. Again, we are unaware of any published studies on the potential associations between ED and endothelin-related gene variants in children.

Based on aforementioned considerations, we aimed to identify single nucleotide polymorphisms (SNPs) in NOS family (3 isoforms), and EDN family (3 isoforms and their 2 cognate receptors) in order to identify potential associations of these SNPs with ED in children.

\section{Methods}

\section{Subjects}

The study was approved by the University of Louisville Human Research Committee (Louisville, KY, USA), and informed consent was obtained from the legal caregiver of each participant. Consecutive healthy pre-pubertal children (ages 5-10 years) were recruited from the community to investigate endothelial function.

\section{Anthropometric characteristics Anthropometry}

Children were weighed using the InBody 320 scale (Biospace; Cerritos, CA), and height (to $0.1 \mathrm{~cm}$ ) was measured using a stadiometer (Holtain, Crosswell, UK). The BMI was calculated and the BMI $z$-score was computed using US Centers for Disease Control and Prevention 2000 growth standards (http://www.cdc.gov/growthcharts/) and online software (http://wwwn.cdc.gov/epiinfo/). A BMI $z$-score $>1.65$ ( $>$ 95th percentile) was considered as fulfilling obesity criteria.

\section{Sphygmomanometry}

All children had arterial blood pressure measured noninvasively using an automated mercury sphygmomanometer (Welch Allyn; Skaneateles Falls, New York) at the brachial artery, using the appropriate cuff size on the nondominant arm [33]. Systolic BP and diastolic BP indices were calculated by dividing the average systolic and diastolic pressure by the respective 95th percentile for BP using National Heart, Lung and Blood Institute guidelines http:/www.nhlbi.nih.gov/guidelines/ hypertension/child_tbl.htm), computed for age, sex, and height. Hypertension was defined when the SBPi or DBPi was $>1$.

\section{Endothelial function tests}

Endothelial function was assessed using a modified hyperemic test after cuff-induced occlusion of the radial and ulnar arteries by placing the cuff over the wrist. All testing was performed in the morning after an overnight fast. A laser Doppler sensor (Periflux 5000 System integrated with the PF 5050 Pressure Unit, Perimed, Järfälla, Sweden) was applied over the volar aspect of the hand at the 1st finger distal metacarpal surface and the hand was gently immobilized. This site was chosen as an area in order to minimize the effects of motion artifact, and was also found to have a density of skin capillary blood flow that was of appropriate magnitude for detection. Children lay supine with the head of the bed elevated $45^{\circ}$. Once cutaneous blood flow over the area became stable, 
the pressure within an inflatable cuff placed at the forearm and connected to a computer- controlled manometer was raised to $200 \mathrm{mmHg}$ for 60 seconds during which blood flow was reduced to undetectable levels. An occlusion time of 60 seconds was chosen in order to minimize discomfort for the child and thus prevent motion and invalidation of the test. Furthermore, we used a computer-controlled pressure release to allow for consistent deflation times. The cuff was rapidly deflated, and the laser Doppler measured hyperemic responses. The maneuver was repeated twice within 10 min with at least 2 min separating both trials to ensure a return to baseline perfusion. The average of both maneuvers was then computed for subsequent analyses, and demonstrated excellent reproducibility [34]. Commercially available software (Perimed, Järfälla, Sweden) allowed for unbiased estimates of the time to peak regional blood flow response post-occlusion release (Tmax), which is considered representative of the hyperemic response and an index of endothelial function [35]. As previously described, we defined abnormal endothelial function as a Tmax cutoff value of $\geq 45$ seconds [34].

\section{Plasma assays}

Fasting blood samples were drawn from the subjects and immediately centrifuged in a cooled centrifuge and plasma was frozen at $-80^{\circ} \mathrm{C}$ until assay, usually within $<2$ weeks from collection. Plasma insulin levels were measured using a commercially available radioimmunoassay kit (Coat-A Count Insulin; Diagnostic Products Inc). This method has a detection level of $1.2 \mu \mathrm{IU} / \mathrm{mL}$ and exhibits linear behavior up to $350 \mu \mathrm{IU} / \mathrm{mL}$, with intra-assay and inter-assay coefficients of variability of $3.1 \%$ and $4.9 \%$, respectively. Plasma glucose level was measured using a commercial kit based on the hexokinase-glucose6-phosphate dehydrogenase method (Flex Reagent Cartridges; Dade Behring, Newark, DE). Insulin resistance was assessed using the homeostasis model assessment (HOMA) equation (fasting insulin $\times$ fasting glucose/22.5) [36]. Plasma hsCRP levels were measured within 2-3 hours after collection using the Flex reagent Cartridge (Date Behring, Newark, DE). This method has a detection level of $0.05 \mathrm{mg} / \mathrm{dl}$, and exhibits linear behavior up to $255 \mathrm{mg} / \mathrm{dl}$, with intra-assay and inter-assay coefficients of variability of $9 \%$ and $18 \%$ respectively for hsCRP. Serum lipids including total cholesterol, highdensity lipoprotein (HDL) cholesterol, calculated lowdensity lipoprotein cholesterol (LDL), and triglycerides (TG) were also assessed using Flex Reagent Cartridges (Dade Behring). To ensure consistency and to prevent protein degradation, particular care was taken to standardize all steps of plasma sample processing and to minimize thawing more than once for each aliquot.

\section{DNA extraction}

Peripheral blood samples were collected in vacutainer tubes containing EDTA (Becton Dickinson, Franklin Lakes, NJ, USA). Genomic DNAs of children were extracted using QIAmp DNA blood kit (Qiagen, Valencia, CA, USA). The concentration and quality of the DNA were determined using a ND-1000 Spectrophotometer (Nanodrop Technologies, Wilmington, DE, USA). The purity of the DNA were determined by calculating the ratio of absorbance at $260 / 280 \mathrm{~nm}$, and all DNA samples had a ratio of 1.8-1.9. The precise length of genomic DNA was determined by gel electrophoresis using $1 \%$ agarose gel. All the purified samples were stored at $-80^{\circ}$ $\mathrm{C}$ until further analyses.

\section{Custom cardiovascular gene SNP array}

The IBC array was developed using SNP and linkage disequilibrium information from the HapMap as well as resequencing data from Seattle SNPs and National Institute of Environmental Health Sciences (NIEHS) SNPs [37]. Briefly, the IBC array contains about 50,000 SNPS from genetic diversity across approximately 2100 genes related to cardiovascular, inflammatory, hemostasis/coagulation, and metabolic phenotypes and pathways. Among those genes, we selected the NOS genes which include NOS1 (209 SNPs), NOS2 (122 SNPs) and NOS3 (50 SNPs). Furthermore we selected the EDN and EDN receptor genes family which includes EDN1 (43 SNPs), EDN2 (48 SNPs), EDN3 (14SNPs), EDNRA (27 SNPs) and EDNRB (23 SNPs). SNPs were clustered into genotypes with the Illumina Beadstudio software and subjected to quality-control filters at the sample and SNP levels separately within each cohort. Samples were excluded for individual call rates $<90 \%$, gender mismatch, and duplicate discordance. SNPs were removed for call rates $<95 \%$ or Hardy-Weinberg Equilibrium $\mathrm{p}<$ $10^{-7}$ in controls from each cohort (regardless of ethnicity). Because of the low-frequency SNPs included in the design and the aim to capture low-frequency variants of large effect across the large dataset, we filtered only on minor allele frequency $(\mathrm{MAF})<0.005$.

\section{Validation of SNP array using real-time PCR}

SNPs that showed statistically significant differences between children with ED and without ED were further validated using TaqMan real-time PCR (Applied Biosystems, Inc.). Two fluorogenic minor groove binder probes were used for each locus using the dyes 6carboxyfluorescein (FAM; excitation, $494 \mathrm{~nm}$ ) and VIC (excitation, $538 \mathrm{~nm}$ ) which are easily differentiated in RTPCR system. The reaction mixture $(25 \mu \mathrm{l}$ total volume per single well reaction) containing $12.5 \mu \mathrm{l}$ of TaqMan $2 \mathrm{X}$ universal master mix (Applied Biosystems, CA), $1.25 \mu \mathrm{l}$ of each primer, $10.25 \mu \mathrm{l}$ of RNase- and DNase-free water 
(Ambion, Austin, TX), and $1 \mu$ l of DNA template. Each sample was duplicated in two wells of a 96 well-plate (Applied Biosystems, CA). DNase-free water used as negative control was included in each assay run. Protocol consisted of $2 \mathrm{~min}$ at $50^{\circ} \mathrm{C}, 10 \mathrm{~min}$ at $95^{\circ} \mathrm{C}$, and 42 cycles of $95^{\circ} \mathrm{C}$ for $15 \mathrm{sec}$ and $60^{\circ} \mathrm{C}$ for $1 \mathrm{~min}$. Initially, the SNP assay was set up using SDS, version 2.1, software (Applied Biosystems, CA) as an absolute quantification assay, but after assay completion the plate was read using the allelic discrimination settings. Post-assay analysis was performed using the SDS software. The goodness-of-fit test for Hardy-Weinberg equilibrium (HWE) was performed after analysis using the equation $\mathrm{p}^{2}+\mathrm{q}^{2}+2 \mathrm{pq}=1$, where $\mathrm{p}$ and $\mathrm{q}$ represent the wild-type and variant allele of a gene.

\section{Total RNA isolation}

Fasting peripheral blood samples were drawn from children within the first hour after awakening and collected in PAXgene Blood RNA tubes (Becton Dickinson, UK). Total RNA was isolated using PAXgene Blood RNA Kit and treated with DNase I (QIAGEN, CA), according to the manufacturer's protocol. The RNA quantity and integrity were determined using a Nanodrop Spectrophotometer and Agilent 2100 Bioanalyzer Nano 6000 LabChip assay (Agilent Technologies).

\section{Gene expression using qRT-PCR}

Quantitative real time RT-PCR (qRT-PCR) analyses were performed using ABI 7500 (Applied Biosystems, Foster City, CA). cDNA synthesis was performed using a HighCapacity cDNA Archive Kit (Applied Biosystems, Foster

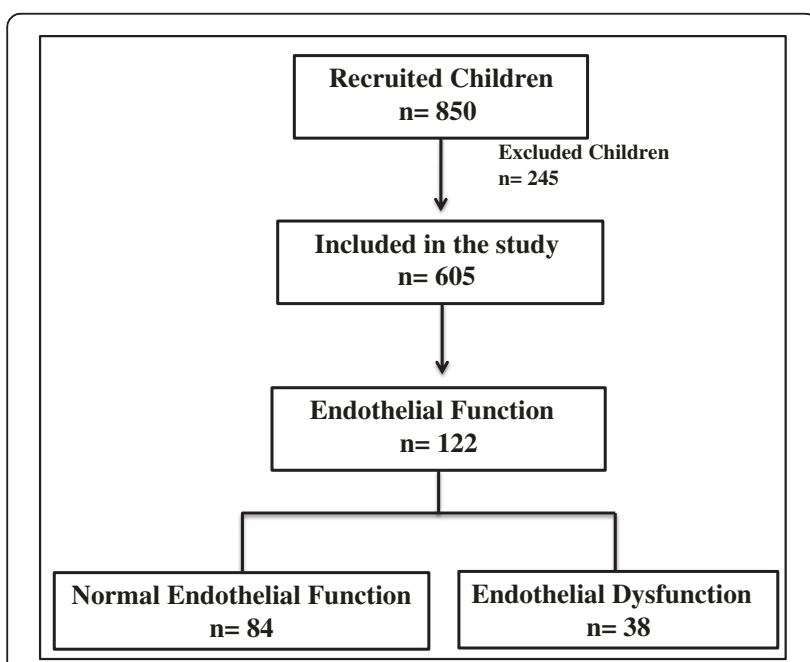

Figure 1 Schematic diagram illustrating the recruitment process. Children were matched for age, gender and ethnicity. Children were excluded from the study, if they had any chronic medical conditions such as known genetic syndromes, severe asthma or allergies, or if they were on any chronic medications.
City, CA). Five hundred nanograms (500 ng) of total RNA from NEF and ED samples were used to generate cDNA templates for RT-PCR. The TaqMan ${ }^{\circledR}$ Master Mix Reagent Kit (Applied Biosystems, Foster City, CA) was used to amplify and quantify each transcript of interest in $25 \mu \mathrm{l}$ reactions. Various negative controls were included in the PCR reaction to ensure specific amplification. Triplicate PCR reactions were performed in 96-well plates for each gene in parallel with the $18 \mathrm{~S}$ rRNA. The steps involved in the reaction program included: the initial step of 2 minutes at $50^{\circ} \mathrm{C}$; denaturation at $95^{\circ} \mathrm{C}$ for $10 \mathrm{~min}$, followed by 45 thermal cycles of denaturation $\left(15\right.$ seconds at $95^{\circ} \mathrm{C}$ ) and elongation $\left(1 \mathrm{~min}\right.$ at $\left.60^{\circ} \mathrm{C}\right)$. The expression values were obtained from the cycle number ( $C t$ value) using the Biosystems analysis software. The threshold cycle $\left(C_{\mathrm{T}}\right)$ values were averaged from each reaction, and each gene was normalized to the $18 \mathrm{~S}$ rRNA level. All the genes of interest and $18 \mathrm{~S}$ rRNA were performed in triplicates to determine the Ctdiff. These $\mathrm{Ct}$ values were averaged and the difference between the $18 \mathrm{~S} \mathrm{Ct}$ (Avg) and the gene of interest $\mathrm{Ct}$ (Avg) was calculated (Ct-diff). The relative expression of the gene of interest was analyzed using the $2^{-\Delta \Delta C T}$ method [38]. Quantitative results are expressed as the

Table 1 Demographic characteristics and metabolic data in children with and without endothelial dysfunction

\begin{tabular}{|c|c|c|c|}
\hline Variables & $\begin{array}{l}\text { Endothelial } \\
\text { function } \\
(\mathrm{n}=84)\end{array}$ & $\begin{array}{l}\text { Endothelial } \\
\text { dysfunction } \\
(\mathrm{n}=38)\end{array}$ & $P$-value \\
\hline Age (years) & $7.60 \pm 1.22$ & $8.05 \pm 1.32$ & 0.14 \\
\hline Gender (\% male) & 70.2 & 63.2 & 0.16 \\
\hline \multicolumn{4}{|l|}{ Ethnicity } \\
\hline White Caucasian \% & 77.9 & 74.3 & 0.19 \\
\hline African American \% & 22.1 & 25.7 & 0.22 \\
\hline${ }^{1} \mathrm{BMI}$ z-score & $0.99 \pm 1.26$ & $1.75 \pm 0.98$ & 0.0002 \\
\hline${ }^{2} \mathrm{SBP}(\mathrm{mmHg})$ & $105.35 \pm 10.84$ & $105.31 \pm 11.12$ & 0.50 \\
\hline${ }^{3} \mathrm{DBP}(\mathrm{mmHg})$ & $62.60 \pm 7.57$ & $62.11 \pm 7.70$ & 0.40 \\
\hline${ }^{4} \mathrm{Tmax}(\mathrm{sec})$ & $27.47 \pm 10.65$ & $61.97 \pm 16.92$ & 0.0001 \\
\hline${ }^{5} \mathrm{TG}(\mathrm{mg} / \mathrm{dl})$ & $71.69 \pm 36.42$ & $88.97 \pm 52.80$ & 0.04 \\
\hline${ }^{6} \mathrm{TC}(\mathrm{mg} / \mathrm{dl})$ & $160.60 \pm 25.99$ & $166.72 \pm 27.12$ & 0.13 \\
\hline${ }^{7} \mathrm{HDL}-\mathrm{C}(\mathrm{mg} / \mathrm{dl})$ & $52.77 \pm 10.46$ & $49.67 \pm 8.66$ & 0.05 \\
\hline${ }^{8} \mathrm{LDL}-\mathrm{C}(\mathrm{mg} / \mathrm{dl})$ & $93.19 \pm 22.11$ & $99.22 \pm 23.68$ & 0.10 \\
\hline Glucose (mg/dl) & $78.72 \pm 16.48$ & $80.59 \pm 13.63$ & 0.28 \\
\hline Insulin (mg/dl) & $6.44 \pm 5.34$ & $8.77 \pm 6.53$ & 0.05 \\
\hline${ }^{9} \mathrm{HOMA}-\mathrm{IR}$ & $1.12 \pm 1.21$ & $1.27 \pm 1.54$ & 0.29 \\
\hline${ }^{10} \mathrm{CRP}(\mathrm{mg} / \mathrm{dl})$ & $1.24 \pm 3.51$ & $1.32 \pm 1.76$ & 0.44 \\
\hline
\end{tabular}

${ }^{1}$ BMI Z-score (body mass index-z-score; ${ }^{2} \mathrm{SBP}$ (systolic blood pressure); ${ }^{3} \mathrm{DBP}$ (diastolic blood pressure); ${ }^{4} \mathrm{Tmax}$ (time of maximum perfusion); ${ }^{5} \mathrm{TG}$ (Triglycerides); ${ }^{6} \mathrm{TC}$ (total cholesterol); ${ }^{7} \mathrm{HDL}-\mathrm{C}$ (high-density lipoprotein)cholesterol; ${ }^{8} \mathrm{LDL}-\mathrm{C}$ (low-density lipoprotein)-cholesterol; ${ }^{9} \mathrm{HOMA}$-IR (homeostatic model assessment-insulin resistance); and ${ }^{10} \mathrm{CRP}$ (C-reactive protein). 
Table 2 Distributions of allele and genotype frequencies of NOS1 SNPs in children with and without endothelial dysfunction

\begin{tabular}{|c|c|c|c|c|c|c|c|c|}
\hline \multirow[t]{2}{*}{ SNP } & \multirow[t]{2}{*}{ Allele } & \multicolumn{2}{|c|}{ Endothelial function } & \multicolumn{2}{|c|}{ Endothelial dysfunction } & \multirow[t]{2}{*}{$P$-value } & \multirow[t]{2}{*}{ OR } & \multirow[t]{2}{*}{$\mathrm{Cl} 95 \%$} \\
\hline & & $\mathrm{n}=8$ & & $\mathrm{n}=$ & & & & \\
\hline \multirow[t]{6}{*}{ rs6490121 } & $A / G$ & $\mathrm{n}$ & $\%$ & $n$ & $\%$ & & & \\
\hline & AA & 31 & 37 & 20 & 53 & 0.046 & 5.26 & $1.16-23.89$ \\
\hline & GA & 34 & 40 & 16 & 42 & & & \\
\hline & GG & 19 & 23 & 2 & 5 & & & \\
\hline & Allele A & 96 & 57 & 56 & 74 & & & \\
\hline & Allele G & 72 & 43 & 20 & 26 & & & \\
\hline \multirow[t]{6}{*}{ rs2293052 } & $\mathrm{C} / \mathrm{T}$ & $\mathrm{n}$ & $\%$ & $\mathrm{n}$ & $\%$ & & & \\
\hline & $\mathrm{CC}$ & 53 & 63 & 16 & 42 & 0.016 & 1.76 & $0.46-6.71$ \\
\hline & $\mathrm{TC}$ & 20 & 24 & 19 & 50 & & & \\
\hline & $\Pi$ & 11 & 13 & 3 & 8 & & & \\
\hline & Allele C & 126 & 75 & 51 & 67 & & & \\
\hline & Allele T & 42 & 25 & 25 & 33 & & & \\
\hline \multirow[t]{6}{*}{ rs3825102 } & $\mathrm{A} / \mathrm{C}$ & $\mathrm{n}$ & $\%$ & $n$ & $\%$ & & & \\
\hline & $\mathrm{AA}$ & 11 & 13 & 2 & 5 & 0.001 & 2.97 & $1.33-6.62$ \\
\hline & $A C$ & 22 & 26 & 23 & 61 & & & \\
\hline & CC & 51 & 61 & 13 & 34 & & & \\
\hline & Allele A & 44 & 26 & 27 & 36 & & & \\
\hline & Allele C & 124 & 74 & 49 & 64 & & & \\
\hline \multirow[t]{6}{*}{ rs4767529 } & $C / G$ & $\mathrm{n}$ & $\%$ & $n$ & $\%$ & & & \\
\hline & CC & 44 & 52 & 12 & 32 & 0.049 & 1.28 & $0.38-4.31$ \\
\hline & GC & 29 & 35 & 22 & 58 & & & \\
\hline & GG & 11 & 13 & 4 & 10 & & & \\
\hline & Allele C & 117 & 70 & 46 & 61 & & & \\
\hline & Allele G & 51 & 30 & 30 & 39 & & & \\
\hline \multirow[t]{6}{*}{ rs561712 } & $A / G$ & $\mathrm{n}$ & $\%$ & $\mathrm{n}$ & $\%$ & & & \\
\hline & $\mathrm{AA}$ & 13 & 15 & 4 & 10 & 0.037 & 2.34 & $1.03-5.32$ \\
\hline & $A G$ & 30 & 36 & 23 & 61 & & & \\
\hline & GG & 41 & 49 & 11 & 29 & & & \\
\hline & Allele A & 56 & 33 & 31 & 41 & & & \\
\hline & Allele G & 112 & 67 & 45 & 59 & & & \\
\hline \multirow[t]{6}{*}{ rs549098 } & $\mathrm{C} / \mathrm{T}$ & $\mathrm{n}$ & $\%$ & $\mathrm{n}$ & $\%$ & & & \\
\hline & CC & 43 & 51 & 11 & 29 & 0.032 & 1.21 & $0.40-3.67$ \\
\hline & $\mathrm{TC}$ & 28 & 33 & 22 & 58 & & & \\
\hline & $\pi$ & 13 & 16 & 5 & 13 & & & \\
\hline & Allele C & 114 & 68 & 44 & 58 & & & \\
\hline & Allele T & 54 & 32 & 32 & 42 & & & \\
\hline \multirow[t]{6}{*}{ rs567581 } & $A / G$ & $\mathrm{n}$ & $\%$ & $\mathrm{n}$ & $\%$ & & & \\
\hline & $\mathrm{AA}$ & 13 & 16 & 5 & 13 & 0.022 & 2.70 & $1.19-6.14$ \\
\hline & $A G$ & 27 & 32 & 22 & 58 & & & \\
\hline & GG & 44 & 52 & 11 & 29 & & & \\
\hline & Allele A & 53 & 32 & 32 & 42 & & & \\
\hline & Allele G & 115 & 68 & 44 & 58 & & & \\
\hline
\end{tabular}


Table 2 Distributions of allele and genotype frequencies of NOS1 SNPs in children with and without endothelial dysfunction (Continued)

\begin{tabular}{|c|c|c|c|c|c|c|c|c|}
\hline \multirow[t]{6}{*}{ rs483589 } & $\mathrm{A} / \mathrm{G}$ & $n$ & $\%$ & $n$ & $\%$ & & & \\
\hline & $\mathrm{AA}$ & 11 & 13 & 11 & 29 & \multirow[t]{5}{*}{0.008} & \multirow[t]{5}{*}{3.58} & \multirow[t]{5}{*}{$1.47-8.70$} \\
\hline & $A G$ & 32 & 38 & 19 & 50 & & & \\
\hline & GG & 41 & 49 & 8 & 21 & & & \\
\hline & Allele A & 54 & 32 & 41 & 54 & & & \\
\hline & Allele G & 114 & 68 & 35 & 46 & & & \\
\hline \multirow[t]{6}{*}{ rs693534 } & $A / G$ & $\mathrm{n}$ & $\%$ & $n$ & $\%$ & & & \\
\hline & $\mathrm{AA}$ & 11 & 13 & 13 & 34 & \multirow[t]{5}{*}{0.011} & \multirow[t]{5}{*}{2.67} & \multirow[t]{5}{*}{$1.15-6.18$} \\
\hline & $A G$ & 32 & 38 & 15 & 40 & & & \\
\hline & GG & 41 & 49 & 10 & 26 & & & \\
\hline & Allele A & 54 & 32 & 41 & 54 & & & \\
\hline & Allele G & 114 & 68 & 35 & 46 & & & \\
\hline \multirow[t]{6}{*}{ rs9658255 } & $C / G$ & $\mathrm{n}$ & $\%$ & $n$ & $\%$ & & & \\
\hline & CC & 41 & 49 & 10 & 26 & \multirow[t]{5}{*}{0.029} & \multirow[t]{5}{*}{0.37} & \multirow[t]{5}{*}{$0.14-0.95$} \\
\hline & GC & 32 & 38 & 17 & 45 & & & \\
\hline & GG & 11 & 13 & 11 & 29 & & & \\
\hline & Allele C & 114 & 68 & 37 & 49 & & & \\
\hline & Allele G & 54 & 32 & 39 & 51 & & & \\
\hline \multirow[t]{6}{*}{ rs1879417 } & $C / T$ & $\mathrm{n}$ & $\%$ & $\mathrm{n}$ & $\%$ & & & \\
\hline & $\mathrm{CC}$ & 14 & 17 & 14 & 37 & \multirow[t]{5}{*}{0.02} & \multirow[t]{5}{*}{2.73} & \multirow[t]{5}{*}{$1.07-6.91$} \\
\hline & $C T$ & 38 & 45 & 17 & 45 & & & \\
\hline & $\pi$ & 32 & 38 & 7 & 18 & & & \\
\hline & Allele C & 66 & 39 & 45 & 59 & & & \\
\hline & Allele T & 102 & 61 & 31 & 41 & & & \\
\hline
\end{tabular}

mean \pm standard deviation (SD). Statistical significance was evaluated by the Student's $t$-test.

\section{Statistical analysis}

All analyses were conducted using SPSS software (version 19.0; SPPS Inc., Chicago, Ill.), and data are presented as mean $\pm \mathrm{SD}$. The association analysis was assessed by using Pearson's chi-square test implemented in SPSS. A $P$-value $<0.05$ was considered statistically significant for all analyses. Odds ratio and 95\% confidence interval were calculated for the minor allele of each SNP. We performed these analyses under the a priori assumption that since candidate-gene studies lack power to detect weak genetic risk effects of common variants, any findings from the current analyses will require cautious interpretation. Indeed, to achieve a power of $>80 \%$ in the detection of a modest genetic risk (e.g., odds ratio $=1.2$ ) for any SNP of interest with a known prevalence of $10 \%$ in the population, a sample size of more than 10,000 subjects would be needed $[39,40]$. The Haploview version 4.2 software (hppt://www.borad.mit. $\mathrm{edu} / \mathrm{mpg} /$ haploview) was used to analyze the linkage disequilibrium structure, calculating D' to define haplotype block [41] and to estimate haplotype frequencies. Additionally, pair-wise linkage disequilibrium (LD) among the SNPs was examined using Lewontin's standardized coefficient D' and LD coefficient $r^{2}$ [42], and haplotype blocks were defined according to the method of Garbriel et al. [41] in Haploview 4.2 with default settings. Haplotypes within these blocks were estimated using the estimation of maximization algorithm [43].

\section{Results}

\section{Cohort phenotype}

Of a potential total of 850 subjects, > 600 subjects were recruited from the community, and of these, 122 children were randomly selected and their endothelial function was tested (Figure 1). Approximately 245 subjects were excluded from the study due to chronic medical conditions such as Down syndrome, craniofacial or known genetic syndromes, a known episode of infection in the eight weeks preceding the sleep study, asthma or allergies receiving specific therapy (desensitization, leukotriene inhibitors, steroids (topical or systemic). Eighty 
four children were found to have NEF and 38 had evidence of ED as defined by their individual Tmax values. The demographic characteristics of these subjects are shown in Table 1 . The BMI- $\mathrm{z}$ score and the proportion of obese children were significantly higher $(P$-value $\leq$ $0.0002)$ in children with ED. However, there were no differences in either systolic or diastolic blood pressures between both groups. The metabolic data for the 2 groups are shown in Table 1 . Only serum triglyceride levels (TG) were significantly higher in children with ED $(P$-value $\leq 0.04)$, with both groups exhibiting similar fasting serum TC, HDL and LDL cholesterol. Similarly, fasting glucose levels were similar, but plasma insulin

(A)

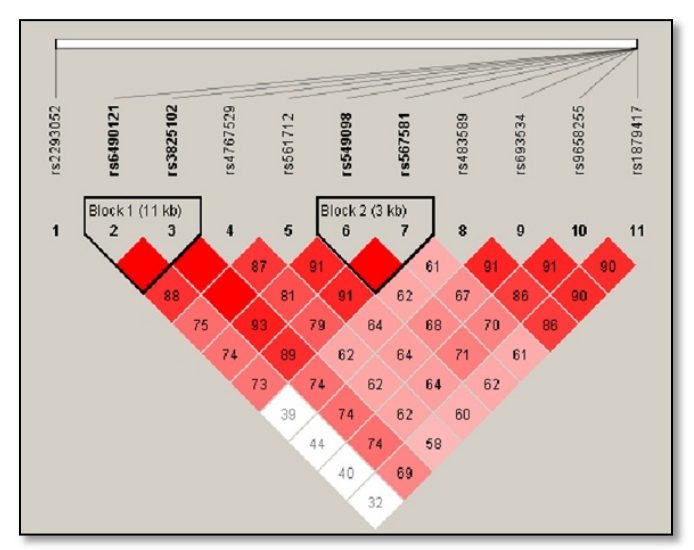

(B)

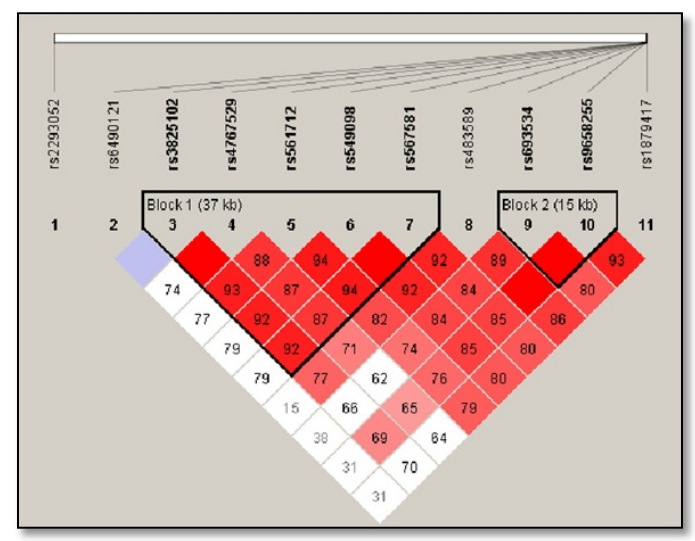

Figure 2 Pairwise linkage disequilibrium (LD) structure and 11 SNPs of the NOS1 gene. Panel (A) represents children with normal endothelial function (NEF), and Panel (B) represents children with endothelial dysfunction (ED). The plot was generated using Haploview 4.2 with $D^{\prime}$ Color Scheme $\left(D^{\prime}=0, D^{\prime}<1\right.$ and $D^{\prime}=1$ shown by white, shades of pink and red (respectively) and pairwise $r^{2}$ values shown in diamonds. The value within each diamond represents the pair-wise LD (correlation, measured as D') between the two SNPs defined by the top left and the top right of the diamond. Solid lines represent SNPs that were used in the haplotype analysis, and are part of the haplotype from SNP block whereas dashed lines represent SNPs that were used in the analysis, but were not part of the haplotype. concentrations were higher in ED children ( $P$-value $\leq 0.05)$. Serum levels of high sensitivity $\mathrm{C}$-reactive protein (hsCRP) were also similar (Table 1).

\section{NOS genes}

As a preamble, all the SNPs tested in this study were in Hardy-Weinberg equilibrium. From a total of 381 SNPs assayed for the 3 NOS genes, 11 SNPs in NOS1 exhibited statistically significant differences in their frequencies among children with and without ED both in the univariate analysis and after correction for multiple comparisons (Table 2). The $P$-value in Table 2 represents the significance of the allele frequency for each SNP. In addition, the odds ratio (OR) and the confidence intervals of $95 \%$ (CI) for all SNPs are shown in Table 2. For example, in addition, to the $P$-value for the allelic frequency, if a SNP presented in Table 2 is higher than 1.0 that indicates this SNPs is significantly associated with ED in the children. Furthermore, all SNPs in Table 2

(A)

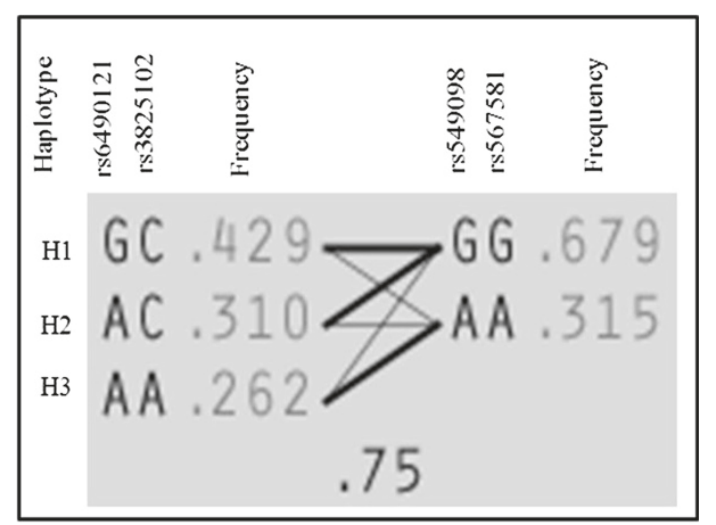

(B)

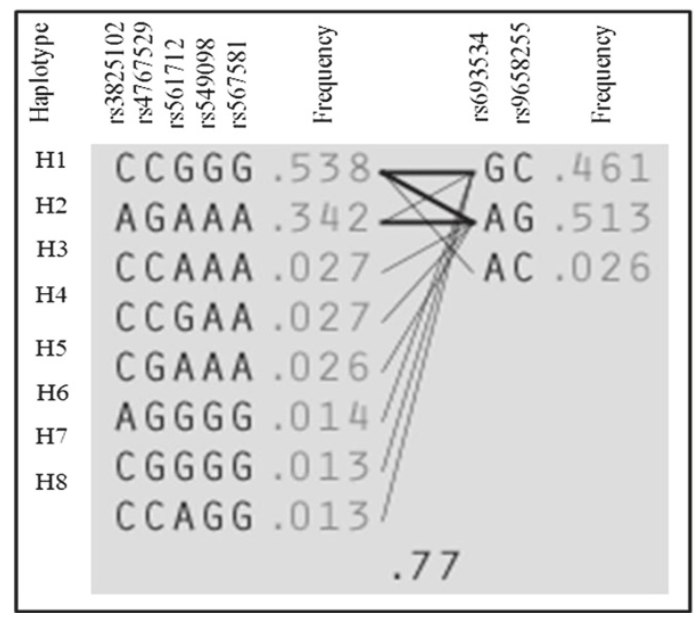

Figure 3 Haplotype frequencies in children with and without endothelial dysfunction. Panel (A) represents haplotype for children with normal endothelial function (NEF), and Panel (B) represents haplotype for children with endothelial dysfunction (ED). 
have a higher OR and CI than 1.0 with the exception of one SNP (rs9658255), indicating that these SNPs are most likely to be associated with ED. No differences emerged for either NOS2 or NOS3 SNPs.

Linkage disequilibrium (LD) analysis of the 11 SNPs in the NOS1 gene was assessed for both NEF and ED subjects. In NEF subjects, two haplotype blocks emerged, and are outlined in black triangular regions in Figure 2 (Panel A). In ED subjects, the haplotype showed the presence of 2 blocks (Figure 2, Panel B). The haplotype of these blocks and their frequencies in NEF and ED are shown in
Figure 3, Panels A and B, respectively. Taken together, the patterns of LD and haplotype frequencies differed between NEF and ED, suggesting that some of these SNPs may contribute to ED risk. Therefore, allelic data were analyzed in conjunction with Tmax values among ED and NEF subjects for the significant NOS1 SNPs as shown in Table 3. Of the 11 significant SNPs of the NOS1 gene, there were only 3 SNPs (rs6490121, rs483589, rs1879417) that showed significantly different Tmax based on the genotype. We found that the A allele in rs6490121 (A/G) and rs483589 (A/G) had significantly higher Tmax than the G

Table 3 Summary of genotypes-phenotypes for NOS1 SNPs that were classified based on Tmax values in all children

\begin{tabular}{|c|c|c|c|c|c|c|}
\hline \multirow{2}{*}{$\frac{\text { Number of significant SNPs }}{1}$} & \multirow{2}{*}{$\begin{array}{l}\text { SNP } \\
\text { rs6490121 }\end{array}$} & \multicolumn{5}{|c|}{ Allele frequencies } \\
\hline & & ${ }^{*} \mathrm{AA}$ & GA & ${ }^{*} \mathrm{GG}$ & ${ }^{*} A A+G A$ & $\mathrm{GG}+\mathrm{GA}$ \\
\hline & $(\mathrm{A} / \mathrm{G})$ & $(n=51)$ & $(n=50)$ & $(n=21)$ & $(n=101)$ & $(n=71)$ \\
\hline & Tmax & $* 39.23 \pm 22.10$ & $39.99 \pm 21.14$ & *31.55 \pm 13.57 & $39.60 \pm 21.53$ & $37.49 \pm 19.51$ \\
\hline \multirow[t]{3}{*}{2} & rs2293052 & CC & $\mathrm{TC}$ & $\pi$ & $\mathrm{CC}+\mathrm{TC}$ & $\pi+\mathrm{TC}$ \\
\hline & $(\mathrm{C} / \mathrm{T})$ & $(n=69)$ & $(n=39)$ & $(n=14)$ & $(n=108)$ & $(n=53)$ \\
\hline & Tmax & $36.50 \pm 19.02$ & $42.13 \pm 23.15$ & $35.80 \pm 20.22$ & $38.53 \pm 20.68$ & $40.45 \pm 22.40$ \\
\hline \multirow[t]{3}{*}{3} & rs3825102 & AA & $A C$ & $\mathrm{CC}$ & $A A+A C$ & $C C+A C$ \\
\hline & $(\mathrm{A} / \mathrm{C})$ & $(n=13)$ & $(n=45)$ & $(n=64)$ & $(n=58)$ & $(n=109)$ \\
\hline & Tmax & $35.02 \pm 20.82$ & $43.95 \pm 24.46$ & $34.84 \pm 16.56$ & $41.95 \pm 23.82$ & $38.60 \pm 20.59$ \\
\hline \multirow[t]{3}{*}{4} & rs4767529 & $\mathrm{CC}$ & GC & GG & $C C+G C$ & $\mathrm{GG}+\mathrm{GC}$ \\
\hline & $(C / G)$ & $(n=56)$ & $(n=51)$ & $(n=15)$ & $(n=107)$ & $(n=66)$ \\
\hline & Tmax & $35.66 \pm 16.94$ & $41.43 \pm 24.04$ & $36.84 \pm 19.90$ & $38.41 \pm 20.74$ & $40.39 \pm 23.10$ \\
\hline \multirow[t]{3}{*}{5} & rs561712 & AA & $A G$ & GG & $A A+A G$ & $\mathrm{GG}+\mathrm{AG}$ \\
\hline & $(A / G)$ & $(n=17)$ & $(n=53)$ & $(n=52)$ & $(n=70)$ & $(n=105)$ \\
\hline & Tmax & $35.26 \pm 19.75$ & $41.67 \pm 23.43$ & $35.66 \pm 17.29$ & $40.12 \pm 22.62$ & $38.70 \pm 20.74$ \\
\hline \multirow[t]{3}{*}{6} & rs549098 & CC & $\mathrm{TC}$ & $\pi$ & $\mathrm{CC}+\mathrm{TC}$ & $\pi+T C$ \\
\hline & $(\mathrm{C} / \mathrm{T})$ & $(n=54)$ & $(n=50)$ & $(n=18)$ & $(n=104)$ & $(n=68)$ \\
\hline & Tmax & $35.21 \pm 16.44$ & $42.04 \pm 24.54$ & $36.61 \pm 18.86$ & $38.50 \pm 20.91$ & $40.60 \pm 23.16$ \\
\hline \multirow[t]{3}{*}{7} & rs567581 & AA & $A G$ & GG & $A A+A G$ & $\mathrm{GG}+\mathrm{AG}$ \\
\hline & $(A / G)$ & $(n=18)$ & $(n=49)$ & $(n=55)$ & $(n=67)$ & $(n=104)$ \\
\hline & Tmax & $36.61 \pm 18.86$ & $42.26 \pm 24.75$ & $35.14 \pm 16.30$ & $40.74 \pm 23.31$ & $38.50 \pm 20.91$ \\
\hline \multirow[t]{3}{*}{8} & rs483589 & ${ }^{*} \mathrm{AA}$ & $A G$ & ${ }^{*} \mathrm{GG}$ & ${ }^{*} A A+A G$ & $\mathrm{GG}+\mathrm{AG}$ \\
\hline & $(\mathrm{A} / \mathrm{G})$ & $(n=22)$ & $(n=51)$ & $(n=49)$ & $(n=73)$ & $(n=100)$ \\
\hline & Tmax & ${ }^{*} 42.88 \pm 19.56$ & $41.56 \pm 23.18$ & *32.65 \pm 16.88 & $* 41.96 \pm 22.02$ & $37.19 \pm 20.73$ \\
\hline \multirow[t]{3}{*}{9} & rs693534 & AA & $A G$ & GG & $A A+A G$ & $G G+A G$ \\
\hline & $(A / G)$ & $(n=24)$ & $(n=47)$ & $(n=51)$ & $(n=71)$ & $(n=98)$ \\
\hline & Tmax & $43.82 \pm 19.41$ & $38.19 \pm 20.74$ & $35.61 \pm 20.79$ & $40.09 \pm 20.34$ & $36.85 \pm 20.70$ \\
\hline \multirow[t]{3}{*}{10} & rs9658255 & $\mathrm{CC}$ & GC & GG & $C C+G C$ & $\mathrm{GG}+\mathrm{GC}$ \\
\hline & $(\mathrm{C} / \mathrm{G})$ & $(n=51)$ & $(n=49)$ & $(n=22)$ & $(n=100)$ & $(n=71)$ \\
\hline & Tmax & $35.22 \pm 20.80$ & $39.53 \pm 20.53$ & $42.24 \pm 19.98$ & $37.33 \pm 20.68$ & $40.37 \pm 20.26$ \\
\hline \multirow[t]{3}{*}{11} & rs1879417 & ${ }^{*} \mathrm{CC}$ & $C T$ & $* T$ & $C C+C T$ & ${ }^{*} T T+C T$ \\
\hline & $(\mathrm{C} / \mathrm{T})$ & $(n=28)$ & $(n=55)$ & $(n=39)$ & $(n=83)$ & $(n=94)$ \\
\hline & Tmax & *45.55 \pm 19.68 & $37.33 \pm 21.45$ & *34.21 \pm 18.97 & $40.10 \pm 21.11$ & $* 36.03 \pm 20.41$ \\
\hline
\end{tabular}


allele (Figure 3, Panels A and B), while the $\mathrm{C}$ allele in rs1879417 (C/T) had significantly higher Tmax values compared to the T allele (Figure 4, Panel C).

\section{Endothelin related genes}

From a total of 155 available SNPs, there were only 2 SNPs in the EDN1 gene whose frequencies differed among children with and without ED. The allele and genotype frequencies of EDN1 SNPs are shown in
Table 4. These 2 EDN1 SNPs were analyzed in conjunction with corresponding Tmax values among ED and NEF subjects. We found that both of these SNPs in EDN1 (rs1476046, rs4714384) showed significant differences in Tmax based on genotype (Table 5). The G allele in $\mathrm{rs} 1476046(\mathrm{~A} / \mathrm{G})$ had a significantly higher Tmax than the A allele (Figure 4, Panel D), and the $\mathrm{T}$ allele in rs4714384 $(\mathrm{C} / \mathrm{T})$ had a significantly higher Tmax than the $\mathrm{C}$ allele (Figure 4, Panel E).

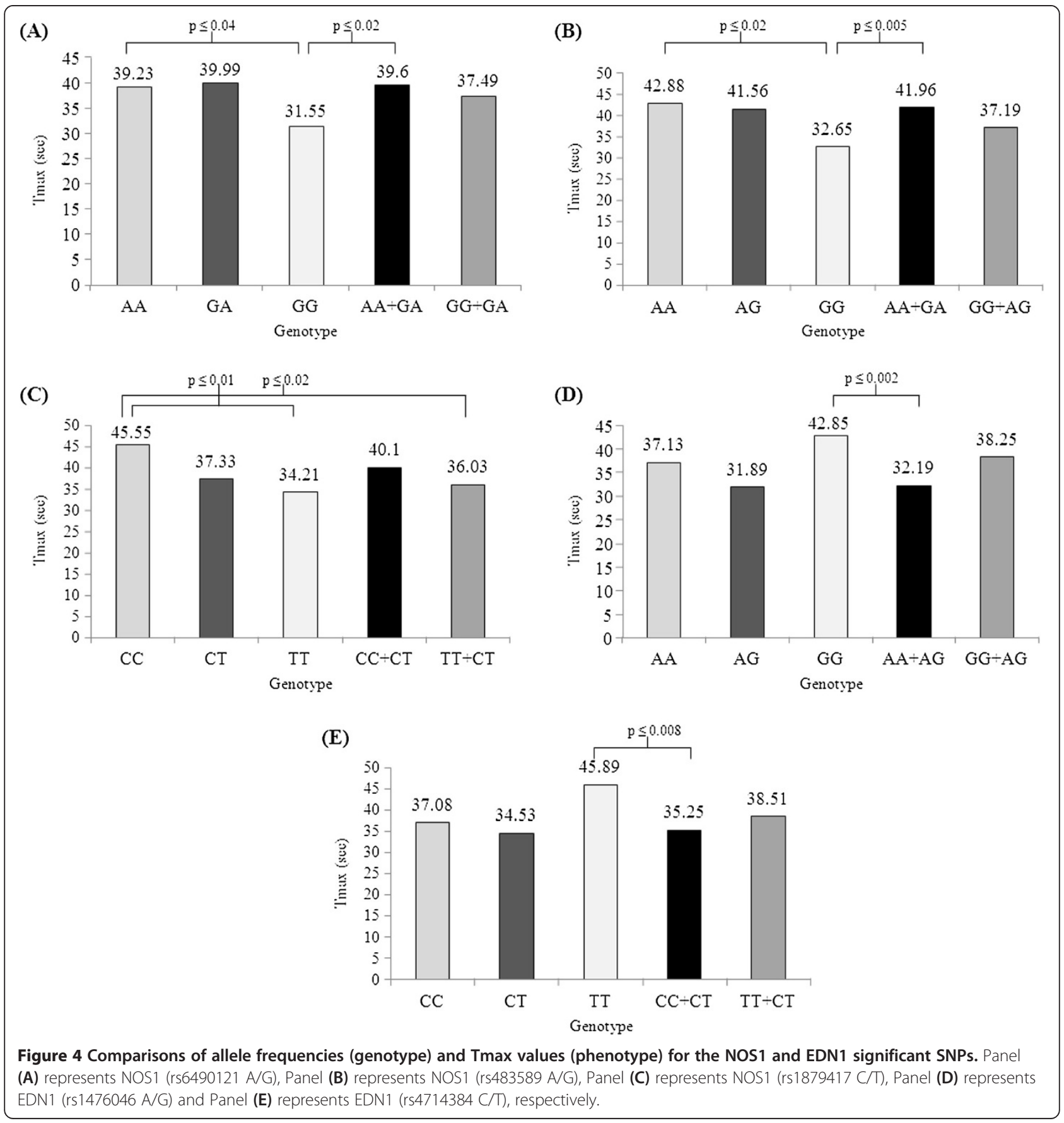


Table 4 Distributions of allele and genotype frequencies for EDN1 SNPs in children with and without endothelial dysfunction

\begin{tabular}{|c|c|c|c|c|c|c|c|c|}
\hline \multirow[t]{2}{*}{ SNP } & \multirow[t]{2}{*}{ Allele } & \multicolumn{2}{|c|}{ Endothelial function } & \multicolumn{2}{|c|}{ Endothelial dysfunction } & \multirow[t]{2}{*}{$P$-value } & \multirow[t]{2}{*}{ OR } & \multirow[t]{2}{*}{$\mathrm{Cl} 95 \%$} \\
\hline & & $\overline{n=\varepsilon}$ & & $\bar{n}=$ & & & & \\
\hline \multirow[t]{6}{*}{ rs1476046 } & $\mathrm{A} / \mathrm{G}$ & $n$ & $\%$ & $n$ & $\%$ & & & \\
\hline & AA & 2 & 2 & 1 & 3 & 0.032 & 0.34 & $0.15-0.79$ \\
\hline & $A G$ & 41 & 49 & 9 & 24 & & & \\
\hline & GG & 41 & 49 & 28 & 73 & & & \\
\hline & Allele A & 45 & 27 & 11 & 15 & & & \\
\hline & Allele G & 123 & 73 & 65 & 85 & & & \\
\hline \multirow[t]{6}{*}{ rs4714384 } & $\mathrm{C} / \mathrm{T}$ & $\mathrm{n}$ & $\%$ & $n$ & $\%$ & & & \\
\hline & CC & 22 & 26 & 3 & 8 & 0.016 & 0.38 & $0.16-0.86$ \\
\hline & $\mathrm{CT}$ & 44 & 52 & 19 & 50 & & & \\
\hline & $\pi$ & 18 & 22 & 16 & 42 & & & \\
\hline & Allele C & 88 & 52 & 25 & 33 & & & \\
\hline & Allele T & 80 & 48 & 51 & 67 & & & \\
\hline
\end{tabular}

\section{qRT-PCR SNP assay validation}

To confirm the SNP array-based findings, we performed qRT-PCR using TaqMan assays with specific primers for some of the SNPs of interest, i.e., those with significantly different frequencies in their allelic genotype frequencies (Additional file 1: Table S1), as well as some of those with significantly different genotype-phenotype allelic frequencies (Additional file 1: Table S1). The concordance findings between array and real-time PCR for allele and genotype frequencies of NOS1 and EDN1 SNPs in children with and without ED are shown in Additional file 2: Table S2. The concordance for both SNPs in the NOS1 gene (rs3825102, rs483589) was 53.21\%, and 61.47\%, respectively and 49\% for EDN1 SNPS (rs1476046, rs4714384). The summary of the validated SNPs data for both NOS1 and EDN1 genes between SNPs array and qRT-PCR is shown in Additional file 3: Table S3.

\section{qRT-PCR gene expression}

Next we asked how the SNPs that putatively affected endothelial function, specifically, their association with gene expression. We selected a total of 20 matched subjects, 10 with endothelial dysfunction (ED), and 10 with normal endothelial function (NEF), and performed gene expression analysis using qRT-PCR. A significant increase in EDN1 gene expression in the peripheral blood of children with ED emerged compared to NEF as illustrated in Figure 5 ( $P$-value 0.0004).

\section{Discussion}

In this study, we report on the associations between the frequency of the 3 NOS genes, and 3 genes of the EDN family, along with its two cognate receptors in a carefully phenotyped cohort of pre-pubertal otherwise healthy community children with and without ED. Not surprisingly, an increased risk of obesity and of increased serum TG levels was present in children with ED. The latter may underlie previously reported lower nitric oxide levels in the context of elevated TG [44]. In addition, the relative frequencies of only a selected few NOS1 and EDN1 gene polymorphisms differed among children with ED, and assessment of Tmax based on allelic variants further confirmed a higher risk of increased Tmax among those children harboring the polymorphic allele.

Before we discuss the potential significance of our findings, some of the strengths and limitations of the

Table 5 Summary of genotypes-phenotypes for EDN1 SNPs that were classified based on Tmax values in all children

\begin{tabular}{|c|c|c|c|c|c|c|}
\hline \multirow{2}{*}{$\frac{\text { Number of significant SNPs }}{1}$} & \multirow{2}{*}{$\begin{array}{l}\text { SNP } \\
\text { EDN1 }\end{array}$} & \multicolumn{5}{|c|}{ Allele frequencies } \\
\hline & & $\mathrm{AA}$ & $A G$ & ${ }^{*} \mathrm{GG}$ & ${ }^{*} A A+A G$ & $\mathrm{GG}+\mathrm{AG}$ \\
\hline & rs1476046(A/G) & $(n=3)$ & $(n=50)$ & $(n=69)$ & $(n=53)$ & $(n=119)$ \\
\hline & Tmax & $37.13 \pm 18.47$ & $31.89 \pm 19.20$ & $* 42.85 \pm 20.62$ & *32.19 \pm 19.03 & $38.25 \pm 20.68$ \\
\hline \multirow[t]{3}{*}{2} & EDN1 & CC & $C T$ & ${ }^{*} T T$ & ${ }^{*} \mathrm{CC}+\mathrm{CT}$ & $\Pi+C T$ \\
\hline & rs4714384 (C/T) & $(n=25)$ & $(n=63)$ & $(n=34)$ & $(n=88)$ & $(n=97)$ \\
\hline & Tmax & $37.08 \pm 23.65$ & $34.53 \pm 17.56$ & $* 45.89 \pm 21.82$ & *35.25 \pm 19.38 & $38.51 \pm 19.81$ \\
\hline
\end{tabular}

*Indicates significant alleles. 


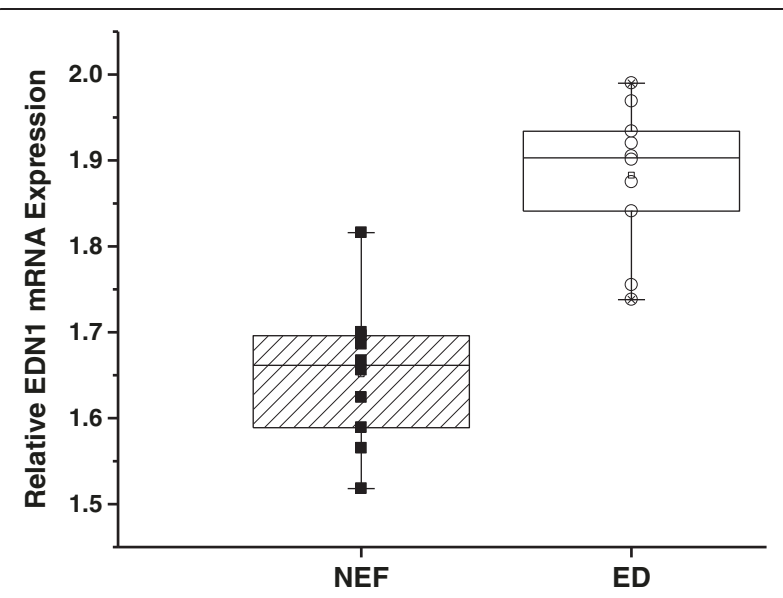

Figure 5 Real-time PCR analysis for EDN1 gene expression in children with normal endothelial function (NEF) and endothelial dysfunction (ED). Total RNA was isolated from peripheral blood and transcribed into cDNA. The data presented as mRNA expression levels normalized to $18 \mathrm{~s}$ ribosomal RNA concentrations. Results are presented as individual values and as boxplots $(P$-value $<0.0004)$.

study should be mentioned. First, the use of the laser Doppler technique for assessment of vascular responses following cuff-induced arterial occlusion not only allows reproducible determinations of the kinetics of postischemic reperfusion, but also provides an accurate reporter of NO-mediated physiological recruitment of the microvasculature [34,45]. The selection of the 60 -seconds occlusion time, rather than the more extensively used 5 minutes in adults, was necessary based on a vast set of preliminary experiments aimed at preventing motioninduced artifacts, and thus preserving the validity of the tests. In addition, all Tmax assessments were conducted in the fasting state at the same time of the day to minimize potential confounders introduced by differences in meal content and timing relative to the testing, and also to ensure that circadian variation in endothelial function would not play a role. An additional strength of the study was the inclusion of a priori healthy children from the community. In addition, we excluded children with a variety of diagnoses that can be associated with endothelial dysfunction [46]. Two important limitations of this study include the relatively small size of the cohort of children studied which could hamper statistical power, and the absence of endothelin plasma level measurements. However, these data may be incorporated into multicenter-based metaanalyses that will undoubtedly enhance the validity of the present putative findings. Finally, in the context of our qRT-pCR validation efforts using TaqMan SNP assays, we found substantial discrepancies between the two methods (i.e., SNP arrays and qRT-PCR), even if the significance of the findings remained unaltered. The concordance between the array data and qRT-PCR revolved around only $50-60 \%$. This was surprising considering that the concordance between gene expression arrays and qRTPCR is remarkably high. It therefore appears that this may not be case for SNP arrays, and the discordant findings necessarily mandate that future studies should require an additional validation step of the array findings using alternative methodologies, an approach that has not been pursued to date while using the same $50 \mathrm{k}$ SNP array as used herein or other commercially available arrays [47-50].

Obesity is a prominent risk factor for the development of cardiovascular disease, diabetes mellitus, dyslipidemia, hypertension, and their constellation as the metabolic syndrome in both adults and children [51-55]. We and others have previously shown that obese children are at higher risk for ED and that both the vasodilatory and vasoconstrictive responses are important. Interestingly, in a recent study Tounian and colleagues reported their analyses of a cohort of 232 severely obese children in whom 12 gene polymorphisms representing selected variants previously associated with vascular ED in adults were examined [56]. These investigators did not find any significant association between flow-mediated vasodilation and any of the 12 SNPs studied. Based on our current findings, we propose that the increased risk for ED in obesity may be explained at least in part by the presence of gene variants in NOS and EDN.

Several studies have investigated the NOS genes family SNPs in relation to different diseases, primarily involving the cardiovascular system [57-60]. In the present study, we found 11 SNPs in the NOS1 gene showing significant differences between children with and without ED. In addition, out of these 11 SNPs, we found 3 SNPs (rs6490121, rs483589, and rs1879417) that were significantly associated with altered Tmax values in children, suggesting that these SNPs carry biological significance. However, no significant differences or associations among SNPs in either NOS2 or NOS3 genes were found.

Similar to studies on NOS gene SNPs, several studies suggest that some of the EDN1 SNPs may be associated with hypertension. For example, EDN1 SNP (rs5370) Lys198Asn (G/T), interactions between BMI and blood pressure emerged in overweight/obese subjects [61-64]. This non-synonymous SNP has already been associated with heart failure and hypertension [61,65]. Furthermore, in rheumatoid arthritis patients who carry the T-T haplotype in EDN1 SNPs (rs1800541 and rs5370), increased systolic blood pressure and high EDN1 plasma levels emerged [66]. In this study, we identified 2 significant SNPs (rs1476046, rs4714384) in the EDN1 gene, and both of these SNPs showed significant differences in Tmax values, adding corroborative evidence to the assumption that these SNPs have biological significance. However, no significant differences emerged in the allelic frequencies in EDN2, EDN3, EDNRA, and EDNRB. 
In summary, significant associations of polymorphisms in NOS and EDN genes are apparent among young children with ED. Of note, EDN1 gene expression appears to be increased in the context of ED. Accordingly; further functional studies are needed to clarify the role of variants of NOS and EDN genes in the pathophysiology of cardiovascular disease.

\section{Additional files}

Additional file 1: Table S1. List of single nucleotide polymorphisms (SNPS) of NOS1 and EDN1 genes.

Additional file 2: Table S2. Distributions of allele and genotype frequencies of NOS1 and EDN1 SNPs in children with and without endothelial dysfunction compare between array and real-time PCR.

Additional file 3: Table S3. Comparison between SNP array and qRT-PCR for NOS1 and EDN1 SNPS.

\section{Competing interests}

The authors declare that they have no competing interests.

\section{Authors' contributions}

SC performed data analysis, and qRT-PCR validation, and help in writing in method section, DG provided the conceptual design of the project, participated in the data analysis and editing final version of the manuscript L K-G participated in recruited subjects, data analysis and sleep studies, R B participated in recruited subjects, AAK participated in genotypic-phenotypic polymorphisms for pairwise linkage disequilibrium structure and haplotype frequencies using Haploview software, YW reviewed data, BK and $\mathrm{HH}$ contributed to genomic polymorphism analyses, WS participated in general discussion and review data, and AK carried data analysis, overall the project and SNPS analysis, writing and editing manuscript. All authors read and approved the final manuscript.

\section{Funding sources}

DG is supported by National Institutes of Health grants HL-065270 and HL-086662. SC is the recipient of the Royal Golden Jubilee Ph. D. Program Award from the Thailand Research Fund (PHD/0138/2552).

\section{Author details}

'Department of Pediatrics, Comer Children's Hospital, Pritzker School of Medicine, Biological Sciences Division, The University of Chicago, 900 E, 57th Street, KCBD, 4112, Chicago 60637, IL, USA. '2Department of Biochemistry, Faculty of Medicine, Srinakharinwirot University, Sukhumvit 23, Bangkok 10110, Thailand. ${ }^{3}$ Center for Applied Genomics, Children's Hospital of Philadelphia, University of Pennsylvania, Philadelphia, PA, USA

Received: 14 May 2013 Accepted: 24 September 2013

Published: 25 September 2013

\section{References}

1. Kelishadi R: Childhood overweight, obesity, and the metabolic syndrome in developing countries. Epidemiol Rev 2007, 29:62-76.

2. Haslam DW, James WP: Obesity. Lancet 2005, 366(9492):1197-1209.

3. Wang Y, Mi J, Shan XY, Wang QJ, Ge KY: Is China facing an obesity epidemic and the consequences? The trends in obesity and chronic disease in China. International journal of obesity 2007, 31(1):177-188.

4. Reilly JJ, Kelly J: Long-term impact of overweight and obesity in childhood and adolescence on morbidity and premature mortality in adulthood: systematic review. International journal of obesity 2011, 35(7):891-898

5. Ribeiro MM, Silva AG, Santos NS, Guazzelle I, Matos LN, Trombetta IC, Halpern A, Negrao CE, Villares SM: Diet and exercise training restore blood pressure and vasodilatory responses during physiological maneuvers in obese children. Circulation 2005, 111(15):1915-1923.

6. Aggoun Y, Farpour-Lambert NJ, Marchand LM, Golay E, Maggio AB, Beghetti $\mathrm{M}$ : Impaired endothelial and smooth muscle functions and arterial stiffness appear before puberty in obese children and are associated with elevated ambulatory blood pressure. Eur Heart J 2008, 29(6):792-799.

7. Bhattacharjee R, Alotaibi WH, Kheirandish-Gozal L, Capdevila OS, Gozal D: Endothelial dysfunction in obese non-hypertensive children without evidence of sleep disordered breathing. BMC pediatrics 2010, 10:8.

8. Gozal D, Kheirandish-Gozal L: Cardiovascular morbidity in obstructive sleep apnea: oxidative stress, inflammation, and much more. Am J Respir Crit Care Med 2008, 177(4):369-375.

9. Davignon J, Ganz P: Role of endothelial dysfunction in atherosclerosis. Circulation 2004, 109(23 Suppl 1):||127-||||32.

10. Hirata Y, Nagata D, Suzuki E, Nishimatsu H, Suzuki J, Nagai R: Diagnosis and treatment of endothelial dysfunction in cardiovascular disease. International heart journal 2010, 51(1):1-6.

11. Versari D, Daghini E, Virdis A, Ghiadoni L, Taddei S: Endothelial dysfunction as a target for prevention of cardiovascular disease. Diabetes Care 2009, 32(Suppl 2):S314-S321.

12. Hingorani AD: Polymorphisms in endothelial nitric oxide synthase and atherogenesis: John French Lecture 2000. Atherosclerosis 2001, 154(3):521-527.

13. Kugiyama K, Yasue $H$, Okumura K, Ogawa H, Fujimoto K, Nakao K Yoshimura M, Motoyama T, Inobe Y, Kawano H: Nitric oxide activity is deficient in spasm arteries of patients with coronary spastic angina. Circulation 1996, 94(3):266-271.

14. Cooke JP, Dzau VJ: Nitric oxide synthase: role in the genesis of vascular disease. Annu Rev Med 1997, 48:489-509.

15. Lamas S, Marsden PA, Li GK, Tempst P, Michel T: Endothelial nitric oxide synthase: molecular cloning and characterization of a distinct constitutive enzyme isoform. Proc Natl Acad Sci USA 1992, 89(14):6348-6352.

16. Bogdan C: Nitric oxide and the immune response. Nature immunology 2001, 2(10):907-916

17. Alderton WK, Cooper CE, Knowles RG: Nitric oxide synthases: structure, function and inhibition. Biochem J 2001, 357(Pt 3):593-615.

18. Hansel TT, Kharitonov SA, Donnelly LE, Erin EM, Currie MG, Moore WM Manning PT, Recker DP, Barnes PJ: A selective inhibitor of inducible nitric oxide synthase inhibits exhaled breath nitric oxide in healthy volunteers and asthmatics. FASEB journal : official publication of the Federation of American Societies for Experimental Biology 2003, 17(10):1298-1300.

19. Cook S, Vollenweider P, Menard B, Egli M, Nicod P, Scherrer U: Increased eNO and pulmonary iNOS expression in eNOS null mice. The European respiratory journal: official journal of the European Society for Clinical Respiratory Physiology 2003, 21(5):770-773.

20. Vaughan DJ, Brogan TV, Kerr ME, Deem S, Luchtel DL, Swenson ER: Contributions of nitric oxide synthase isozymes to exhaled nitric oxide and hypoxic pulmonary vasoconstriction in rabbit lungs. American journal of physiology Lung cellular and molecular physiology 2003, 284(5):L834-L843.

21. Silkoff PE, McClean PA, Slutsky AS, Furlott HG, Hoffstein E, Wakita S, Chapman KR, Szalai JP, Zamel N: Marked flow-dependence of exhaled nitric oxide using a new technique to exclude nasal nitric oxide. Am J Respir Crit Care Med 1997, 155(1):260-267.

22. Alvarez R, Gonzalez P, Batalla A, Reguero JR, Iglesias-Cubero G, Hevia S, Cortina A, Merino E, Gonzalez I, Alvarez V, et al: Association between the NOS3 (-786 T/C) and the ACE (I/D) DNA genotypes and early coronary artery disease. Nitric oxide : biology and chemistry/official journal of the Nitric Oxide Society 2001, 5(4):343-348.

23. Salazar LA, Hirata MH, Giannini SD, Forti N, Diament J, Lima TM, Hirata RD: Seven DNA polymorphisms at the candidate genes of atherosclerosis in Brazilian women with angiographically documented coronary artery disease. Clinica chimica acta; international journal of clinical chemistry 2000, 300(1-2):139-149.

24. Zanchi A, Moczulski DK, Hanna LS, Wantman M, Warram JH, Krolewski AS: Risk of advanced diabetic nephropathy in type 1 diabetes is associated with endothelial nitric oxide synthase gene polymorphism. Kidney Int 2000, 57(2):405-413.

25. Wang $X \mathrm{~L}$, Wang J: Endothelial nitric oxide synthase gene sequence variations and vascular disease. Mol Genet Metab 2000, 70(4):241-251.

26. Zintzaras E, Kitsios G, Stefanidis I: Endothelial NO synthase gene polymorphisms and hypertension: a meta-analysis. Hypertension 2006, 48(4):700-710.

27. Brunner F, Bras-Silva C, Cerdeira AS, Leite-Moreira AF: Cardiovascular endothelins: essential regulators of cardiovascular homeostasis. Pharmacology \& therapeutics 2006, 111(2):508-531. 
28. Colombo MG, Ciofini E, Paradossi U, Bevilacqua S, Biagini A: ET-1 Lys198Asn and $\mathrm{ET}(\mathrm{A})$ receptor $\mathrm{H} 323 \mathrm{H}$ polymorphisms in heart failure. A casecontrol study. Cardiology 2006, 105(4):246-252.

29. Herrmann S, Schmidt-Petersen K, Pfeifer J, Perrot A, Bit-Avragim N, Eichhorn C, Dietz R, Kreutz R, Paul M, Osterziel KJ: A polymorphism in the endothelin-A receptor gene predicts survival in patients with idiopathic dilated cardiomyopathy. Eur Heart J 2001, 22(20):1948-1953.

30. Telgmann R, Harb BA, Ozcelik C, Perrot A, Schonfelder J, Nonnenmacher A Brand M, Schmidt-Petersen K, Dietz R, Kreutz R, et al: The G-231A polymorphism in the endothelin-A receptor gene is associated with lower aortic pressure in patients with dilated cardiomyopathy. American journal of hypertension 2007, 20(1):32-37.

31. Li H, Louey JW, Choy KW, Liu DT, Chan WM, Chan YM, Fung NS, Fan BJ, Baum L, Chan JC, et al: EDN1 Lys198Asn is associated with diabetic retinopathy in type 2 diabetes. Mol Vis 2008, 14:1698-1704.

32. Yasuda H, Kamide K, Takiuchi S, Matayoshi T, Hanada H, Kada A, Yang J, Miwa Y, Yoshii M, Horio T, et al: Association of single nucleotide polymorphisms in endothelin family genes with the progression of atherosclerosis in patients with essential hypertension. J Hum Hypertens 2007, 21(11):883-892.

33. National High Blood Pressure Education Program Working Group on High Blood Pressure in C, Adolescents: The fourth report on the diagnosis, evaluation, and treatment of high blood pressure in children and adolescents. Pediatrics 2004, 114(2 Suppl 4th Report):555-576.

34. Bhattacharjee R, Kim J, Alotaibi WH, Kheirandish-Gozal L, Capdevila OS, Gozal D: Endothelial dysfunction in children without hypertension: potential contributions of obesity and obstructive sleep apnea. Chest 2012, 141(3):682-691.

35. Wahlberg E, Olofsson P, Swendenborg J, Fagrell B: Changes in postocclusive reactive hyperaemic values as measured with laser Doppler fluxmetry after infrainguinal arterial reconstructions. Eur J Vasc Endovasc Surg 1995, 9(2):197-203.

36. Matthews DR, Hosker JP, Rudenski AS, Naylor BA, Treacher DF, Turner RC: Homeostasis model assessment: insulin resistance and beta-cell function from fasting plasma glucose and insulin concentrations in man. Diabetologia 1985, 28(7):412-419.

37. Keating BJ, Tischfield S, Murray SS, Bhangale T, Price TS, Glessner JT, Galver L, Barrett JC, Grant SF, Farlow DN, et al: Concept, design and implementation of a cardiovascular gene-centric $50 \mathrm{k}$ SNP array for large-scale genomic association studies. PLoS One 2008, 3(10):e3583.

38. Livak KJ, Schmittgen TD: Analysis of relative gene expression data using real-time quantitative PCR and the 2(-Delta Delta $C(T)$ ) Method. Methods 2001, 25(4):402-408.

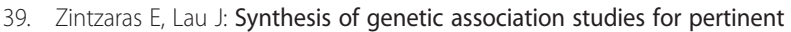
gene-disease associations requires appropriate methodological and statistical approaches. JCE 2008, 61(7):634-645.

40. Zintzaras E, Lau J: Trends in meta-analysis of genetic association studies. J Hum Genet 2008, 53(1):1-9.

41. Gabriel SB, Schaffner SF, Nguyen H, Moore JM, Roy J, Blumenstiel B, Higgins J, DeFelice M, Lochner A, Faggart M, et al: The structure of haplotype blocks in the human genome. Science 2002, 296(5576):2225-2229.

42. Lewontin RC: On measures of gametic disequilibrium. Genetics 1988, 120(3):849-852.

43. Schaid DJ, Rowland CM, Tines DE, Jacobson RM, Poland GA: Score tests for association between traits and haplotypes when linkage phase is ambiguous. Am J Hum Genet 2002, 70(2):425-434.

44. Sarwar N, Danesh J, Eiriksdottir G, Sigurdsson G, Wareham N, Bingham S, Boekholdt SM, Khaw KT, Gudnason V: Triglycerides and the risk of coronary heart disease: 10,158 incident cases among 262,525 participants in 29 Western prospective studies. Circulation 2007, 115(4):450-458.

45. Medow MS, Taneja I, Stewart JM: Cyclooxygenase and nitric oxide synthase dependence of cutaneous reactive hyperemia in humans. American journal of physiology Heart and circulatory physiology 2007, 293(1):H425-H432

46. Valle Jimenez M, Estepa RM, Camacho RM, Estrada RC, Luna FG, Guitarte FB: Endothelial dysfunction is related to insulin resistance and inflammatory biomarker levels in obese prepubertal children. European journal of endocrinology/European Federation of Endocrine Societies 2007, 156(4):497-502.
47. Talmud PJ, Cooper JA, Gaunt T, Holmes MV, Shah S, Palmen J, Drenos F, Shah T, Kumari M, Kivimaki M, et al: Variants of ADRA2A are associated with fasting glucose, blood pressure, body mass index and type 2 diabetes risk: meta-analysis of four prospective studies. Diabetologia 2011, 54(7):1710-1719.

48. Fox ER, Young JH, Li Y, Dreisbach AW, Keating BJ, Musani SK, Liu K, Morrison AC, Ganesh S, Kutlar A, et al: Association of genetic variation with systolic and diastolic blood pressure among African Americans: the Candidate Gene Association Resource study. Hum Mol Genet 2011, 20(11):2273-2284.

49. Ronald J, Rajagopalan R, Cerrato F, Nord AS, Hatsukami T, Kohler T, Marcovina S, Heagerty P, Jarvik GP: Genetic variation in LPAL2, LPA, and PLG predicts plasma lipoprotein(a) level and carotid artery disease risk. Stroke; a journal of cerebral circulation 2011, 42(1):2-9.

50. Saleheen D, Alexander M, Rasheed A, Wormser D, Soranzo N, Hammond N, Butterworth A, Zaidi M, Haycock P, Bumpstead S, et al: Association of the 9p21.3 locus with risk of first-ever myocardial infarction in Pakistanis: case-control study in South Asia and updated meta-analysis of Europeans. Arterioscler Thromb Vasc Biol 2010, 30(7):1467-1473

51. Van Gaal LF, Mertens IL, De Block CE: Mechanisms linking obesity with cardiovascular disease. Nature 2006, 444(7121):875-880.

52. Freedman DS, Dietz WH, Srinivasan SR, Berenson GS: The relation of overweight to cardiovascular risk factors among children and adolescents: the Bogalusa Heart Study. Pediatrics 1999, 103(6 Pt 1):1175-1182

53. Morrison JA, Laskarzewski PM, Rauh JL, Brookman R, Mellies M, Frazer M, Khoury P, deGroot I, Kelly K, Glueck CJ: Lipids, lipoproteins, and sexual maturation during adolescence: the Princeton maturation study. Metabolism 1979, 28(6):641-649.

54. Pinhas-Hamiel O, Dolan LM, Daniels SR, Standiford D, Khoury PR, Zeitler P: Increased incidence of non-insulin-dependent diabetes mellitus among adolescents. J Pediatr 1996, 128(5 Pt 1):608-615.

55. Sinha R, Fisch G, Teague B, Tamborlane WV, Banyas B, Allen K, Savoye M, Rieger V, Taksali S, Barbetta G, et al: Prevalence of impaired glucose tolerance among children and adolescents with marked obesity. $N$ Engl J Med 2002, 346(11):802-810

56. Tounian A, Aggoun Y, Lacorte JM, Dubern B, Clement K, Bonnet D, Tounian $P$ : Influence of polymorphisms in candidate genes on early vascular alterations in obese children. Archives of cardiovascular diseases 2010, 103(1):10-18.

57. Lillie EO, Mahata M, Khandrika S, Rao F, Bundey RA, Wen G, Chen Y, Taupenot L, Smith DW, Mahata SK, et al: Heredity of endothelin secretion: human twin studies reveal the influence of polymorphism at the chromogranin A locus, a novel determinant of endothelial function. Circulation 2007, 115(17):2282-2291.

58. Gormley K, Bevan S, Hassan A, Markus HS: Polymorphisms in genes of the endothelin system and cerebral small-vessel disease. Stroke; a journal of cerebral circulation 2005, 36(8):1656-1660.

59. Dell'Omo G, Penno G, Pucci L, Fotino C, Lucchesi D, Del Prato S, Pedrinelli R: Lack of association between endothelial nitric oxide synthase gene polymorphisms, microalbuminuria and endothelial dysfunction in hypertensive men. J Hypertens 2007, 25(7):1389-1395.

60. Song XY, Lee SY, Ma RC, So WY, Cai JH, Tam C, Lam V, Ying W, Ng MC, Chan JC: Phenotype-genotype interactions on renal function in type 2 diabetes: an analysis using structural equation modelling. Diabetologia 2009, 52(8):1543-1553.

61. Tiret L, Poirier O, Hallet V, McDonagh TA, Morrison C, McMurray JJ, Dargie HJ, Arveiler D, Ruidavets JB, LuC G, et al: The Lys198Asn polymorphism in the endothelin-1 gene is associated with blood pressure in overweight people. Hypertension 1999, 33(5):1169-1174.

62. Asai T, Ohkubo T, Katsuya T, Higaki J, Fu Y, Fukuda M, Hozawa A, Matsubara M, Kitaoka H, Tsuji l, et al: Endothelin-1 gene variant associates with blood pressure in obese Japanese subjects: the Ohasama Study. Hypertension 2001, 38(6):1321-1324

63. Jin JJ, Nakura J, Wu Z, Yamamoto M, Abe M, Tabara Y, Yamamoto Y, Igase M, Kohara K, Miki T: Association of endothelin-1 gene variant with hypertension. Hypertension 2003, 41(1):163-167.

64. Barath A, Endreffy E, Bereczki C, Gellen B, Szucs B, Nemeth I, Turi S: Endothelin-1 gene and endothelial nitric oxide synthase gene polymorphisms in adolescents with juvenile and obesity-associated hypertension. Acta Physiologica 2007, 94(1-2):49-66. 
65. Pare G, Serre D, Brisson D, Anand SS, Montpetit A, Tremblay G, Engert JC, Hudson TJ, Gaudet D: Genetic analysis of 103 candidate genes for coronary artery disease and associated phenotypes in a founder population reveals a new association between endothelin-1 and highdensity lipoprotein cholesterol. Am J Hum Genet 2007, 80(4):673-682.

66. Panoulas VF, Douglas KM, Smith JP, Taffe P, Stavropoulos-Kalinoglou A Toms TE, Elisaf MS, Nightingale P, Kitas GD: Polymorphisms of the endothelin-1 gene associate with hypertension in patients with rheumatoid arthritis. Endothelium : journal of endothelial cell research 2008, 15(4):203-212.

doi:10.1186/1479-5876-11-227

Cite this article as: Chatsuriyawong et al:: Genetic variance in Nitric Oxide Synthase and Endothelin Genes among children with and without Endothelial Dysfunction. Journal of Translational Medicine 2013 11:227.

\section{Submit your next manuscript to BioMed Central and take full advantage of:}

- Convenient online submission

- Thorough peer review

- No space constraints or color figure charges

- Immediate publication on acceptance

- Inclusion in PubMed, CAS, Scopus and Google Scholar

- Research which is freely available for redistribution 